\title{
KOMERCIJALIZACIJA KULTURNE BAŠTINE U TURIZMU Mauro Dujmović
}

\author{
Fakultet ekonomije i turizma „Dr. Mijo Mirkovic““ \\ Sveučilište Jurja Dobrile u Puli \\ Preradovićeva 1/1, 52100 Pula \\ e-mail: mauro.dujmovic@unipu.hr
}

\begin{abstract}
Sažetak
Upostmodernom društvu turizam postaje roba namijenjena potrošnji. Povijest, vrijeme i prostor, kao aspekti kulture, pretvaraju se u robu namijenjenu tržištu. U općoj merkantilizaciji stvarnosti, sve se vrednuje i prodaje kroz prizmu turizma. Kultura je institucionalizirana, kategorizirana i spremna za uporabu, a tradicije se uprizoruju i oživljavaju. Međutim, nisu sva komercijalna dobra i usluge koje povećavaju stopu nacionalnog bruto proizvoda, objektivno prikladna za pojedince, društvo i prirodu. Turizam bi komercijalizacijom i komodifikacijom kulture i načina života mogao uništiti autentičnost destinacija. Turizam mora, uz ekonomsku, imati i sadržajnu komponentu, onu koja će ljudima omogućiti produktivno, korisno, kulturno, sadržajno odmaranje; nešto što će im omogućiti afirmaciju njihovih stvaralačkih sposobnosti $i$ interesa te unaprijediti ličnost. Zato je potrebno razvijati selektivne oblike turizma, tzv. turizam specijalnog interesa da bismo obogatili i oplemenili masovni turizam, prosirili strukturu i produžili vremenski ciklus ponude.
\end{abstract}

Ključne riječi: komercijalizacija, komodifikacija, turizam, turizam naslijeđa, baština, turizam specijalnog interesa, masovni turizam, autentičnost, destinacija

\section{UVOD}

U posljednja dva desetljeća 20. st. dolazi do najspektakularnijeg razvoja turizma kako u razvijenim zemljama, tako i u zemljama u razvoju. Turizam je i danas jedan od najbrže rastućih ekonomskih sektora i glavni izvor zapošljavanja i investicija. U razvijenim zemljama taj razvitak događa se usporedo s povećanjem količine slobodnog vremena, raspoloživog dohotka, povećane mobilnosti, tehnološkog napretka u komunikacijama i transportu, demografskih promjena i postaje čimbenikom promjene u suvremenom svijetu. Fazu zrelog turističkog razvoja od 60-tih i 70-tih godina 20. stoljeća obilježava izrazita konkurentnost turističke ponude na globalnom i nacionalnim tržištima. Turistička su odredišta danas u situaciji da moraju nuditi sofisticirane i atraktivne lokacije i sadržaje te uvijek izmišljati nove kako bi se pozicionirale i etablirale nudeći različitu i jedinstvenu ponudu u odnosu na konkurenciju. Na taj će način izbjeći opasnost da postanu slične drugima što je često rezultat prodora multinacionalnih kompanija, in- 
ternacionalne popularne kulture i samih turista. Drugim riječima, zbog sve veće sofisticiranosti turističkog proizvoda u današnje vrijeme turističke destinacije nastoje kreirati jedinstvene identitete i turističke proizvode kako bi preživjele na sve konkurentnijem globalnom turističkom tržištu i kako bi se međusobno što više razlikovale jedne od drugih te ponudile nešto izvornije i drukčije. Takva konkurentnost posljedica je globalizacije, tj. prostorno vremenske kompresije kapitala i putovanja što prisiljava mnogobrojne destinacije da pokušaju privući investicije, radnu snagu i turiste.

Fenomen prostorno vremenskog sažimanja od izuzetne je važnosti za turizam jer tvori novo povijesno razdoblje tzv. bliske udaljenosti (engl. contiguous distance), a Pierre Bourdieu smatra da su temelji takvog društva uspostavljeni početkom 20. stoljeća, odnosno nakon 1980. (Bourdieu, 1984). Kao rezultat toga, svaka država ili regija u svijetu ima potencijala i resursa za razvoj turizma i turizam je ključni element nacionalnih razvojnih strategija i važno oružje u rukama raznih vlada kao pokretača ekonomske obnove. Malo je danas područja, regija i destinacija u svijetu koje nisu pretvorene u prostore turističke potrošnje i postoji tendencija komercijalizacije prostora, prirode, kulture i turističkih aktivnosti. Turizam je postao sastavni dio konzumerizma i usmjeren je na proizvodnju i zadovoljavanje želje.

\section{KOMERCIJALIZACIJA TURIZMA}

Konzumerizam je toliko ukorijenjen u životima ljudi da mu se oni nesvjesno i rutinski prepuštaju i ima presudni utjecaj na njihova svakodnevna iskustva. Termin potrošač$k o$ sve se više rabi, a označava promjenu stila života, načina razmišljanja i ponašanja uopće. Razvitkom kapitalizma i globalizacijom širi se i konzumerizam. Konzumerizam strukturira naše svakodnevne živote i upotrijebiti pojam konzumerizma ili potrošačke kulture znači naglasiti da su svijet dobara i njegovi principi strukturacije centralni za razumijevanje suvremenog društva. Konzumerizam se često upotrebljava za opisivanje života koji je previše ili totalno zaokupljen potrošnjom i u tom kontekstu termin konzumerizam ima negativan predznak. Iako je očito da je danas konzumerizam način života i da živimo okruženi potrošačkim dobrima i proizvodima, to nužno ne znači da oni negativno utječu na naše živote. Važno je ovdje napomenuti da namjera ovog poglavlja nije moraliziranje ili moralno osuđivanje konzumerizma, već je on shvaćen kao područje konstrukcije ukupnog načina života neke zajednice ili društva u cjelini.

Nema sumnje da je potrošačka kultura dijete globalizacije i da zapravo predstavlja skup vjerovanja i vrijednosti koje posjedovanje materijalnih dobara stavljaju iznimno visoko na listu prioriteta. Kultura konzumerizma odlika je suvremenog društva i to je ideja o kulturi kojoj je središnja preokupacija potrošnja. U postmodernom društvu turizam postaje roba namijenjena potrošnji. Turizam se promatra kao proizvod, a turist kao potrošač koji ga odabire. Naime, turizam se nudi i promovira na specifičnom turističkom tržištu. Tu se prodaje i kupuje, a upravo je takav pristup uvjetovao razvoj tzv. turističke industrije i turistifikaciju turističkog odredišta. 
Konzumerizam je u turizmu povezan $s$ procesom komodifikacije ili komercijalizacije. Komercijalizacija je proces pridruživanja ekonomske vrijednosti, tj. razmjenske vrijednosti stvarima i njihovo pretvaranje u robu na tržištu. Robu, kao i svaku drugu stvar, odlikuje njezina uporabna vrijednost, međutim roba, za razliku od stvari, posjeduje i razmjensku vrijednost, koja je čini podložnom tržišnim zakonima. Njezina cijena na tržištu određena je ekonomskim zakonima ponude i potražnje. U suvremenom je svijetu malo objekata, prostora ili površina koji nisu podvrgnuti komercijalizaciji i moglo bi se reći da u tu skupinu još uvijek spadaju površine ili objekti (javni parkovi, igrališta, šetnice...) namijenjeni javnom dobru, ali se veoma često nalaze u jako lošem stanju zbog nedostatnih financijskih ulaganja, budući da lokalne vlasti uvijek imaju neke druge prioritete. $S$ druge strane postoje prostori, površine, zanimljive i atraktivne lokacije koje su komercijalizirane u turističke svrhe. Međutim, to ne znači da je moguće nalijepiti cijenu na objekte poput Stonehengea, iako jednom kada je objekt komodificiran samo oni koji imaju sredstva da plate prodajnu cijenu, tj. ulaznicu, imaju pravo doživjeti i iskusiti tu robu ili uslugu. U postmodernom društvu objekti postaju komodificirane i zapakirane reprezentacije namijenjene potrošnji. Realnost ustupa mjesto reprezentaciji, a realno gubi svoj značaj i smisao. Povijest, vrijeme i prostor, kao aspekti kulture, pretvaraju se u robu namijenjenu tržištu.

Korijene konzumerizma u turizmu potrebno je potražiti u pojavnostima kao što su a) demokratizacija dokolice i širenje turizma na sve segmente društva; b) industrijalizacija dokolice, tj. primjena fordističkih principa proizvodnje na turizam koji uključuju standardizirane proizvode, jeftine paket-aranžmane, itd. i c) konzumacija tople klime i morskih užitaka koji se povezuju sa 5 S: 1) sun (sunce); 2) sex (seks); 3) sights (vidici, prizori); 4) savings (uštede), 5) servility (uslužnost) (Crick, 1989). Lash i Urry (1993) smatraju kako su organizacija putovanja, izgradnja hotela u kasnom 19. stoljeću, razvoj kampova između dva svjetska rata, poslijeratni razvitak paket-aranžmana u kombinaciji s porastom raspoloživih primanja i pojava dokolice rezultirali su potražnjom za putovanjem na tržištu sjeverne Europe. Još je 1841. godine Thomas Cook shvatio prednosti masovnog turizma i počeo iz njega izvlačiti profit. Iako je i sam Cook opisao svoje rano poduzetničko iskustvo u turizmu kao rad iz ljubavi bez zarade engl. labour of love minus profit, prilično je jasno da je komodifikacijom turizma, tj. prodajom paket-aranžmana putem svojih inovacija (karte kupljene unaprijed za različita sredstva transporta, vodiči, željeznički kupon, hotelski kupon, cirkularna pisma (preteča čekova), zbrinjavanje prtljage koja putuje odvojeno od putnika, all-inclusive putovanje i sl.), ostvario značajan profit. Cook 1879. godine osniva prvu vlastitu poslovnu banku kao centralnu novčarsku instituciju koja radi s Cookovim putničkim čekom i kreditnim pismima. Tvrtka mijenja ime u Thomas Cook \& Son i postaje institucija Britanskog imperija. Tako je nastala prva suvremena putnička agencija i udareni su temelji organiziranog turističkog putovanja, te posredovanja u putovanju koje danas poprima neslućene razmjere (Čavlek, 1998).

Nakon toga, počinje se govoriti o ozbiljnim prihodima od turizma. Sve se intenzivira pojavom sindikalnih zahtjeva za skraćenjem radnoga vremena, a postupno uvođenje 
kraćega radnog dana otvara brojne mogućnosti za razvoj turizma. Primjerice, u Francuskoj prije početka Drugog svjetskog rata državni službenici (željezničari, rudari, općinari, bankari i drugi) potpisuju statute u kojima im se dopušta 15 dana odmora, a 1936. godine jednoglasno je donesen zakon koji osigurava svim zaposlenicima 15 dana plaćenog odmora. Francuska je jedna od prvih država u kojoj je osnovan i Nacionalni ured za turizam (Štifanić, 2002).

Turistička su kretanja, prema svojim značajkama, aktivnost osjetljiva na ratove i društvena previranja, tako da su ekonomska recesija 1930. godine u kombinaciji s dva svjetska rata u prvoj polovici 20 st. u velikoj mjeri ograničila razvoj i daljnju komodifikaciju turizma. Kada piše o razvoju masovnog turizma u Njemačkoj neposredno prije i za vrijeme Drugog svjetskog rata Baranowski (2004) smatra da je država poticala turizam, ali isključivo u svrhu jačanja nacionalne / nacionalističke svijesti. Naime, radilo se o domaćem turizmu, odnosno nizu discipliniranih i komodificiranih putovanja unutar zemlje (što je i inače obilježje modela turizma nedemokratskih režima), koja nisu polučila očekivani moralni, koliko ekonomski uspjeh.

Poslije 1945. godine masovni turizam poprima međunarodni karakter. Mediteran postaje glavno europsko odredište, a Karibi glavna američka destinacija za odmor, a sve zahvaljujući daljnjem napretku transporta, povećanju raspoloživog dohotka i poboljšanju međunarodnih odnosa u svijetu.

1950. i 1960. dolazi do restrukturiranja masovnog turizma. Turizam postaje masovan, sa svim popratnim pojavama koje masovnost uvjetuje. Pojavljuje se pojam „paket-aranžman“, a dolazi i do prvog unajmljivanja zrakoplova za organizirani prijevoz putnika. Prvi čarterski let organizirao je Vladimir Raitz, novinar koji je svu svoju imovinu uložio u taj, tada, vrlo riskantan potez i postigao uspjeh (Štifanić, 2002). Procesi komodifikacije u turizmu doveli su do ekspanzije masovnog turizma i putovanja turista u različite svjetske destinacije izvan mediteranskog i karipskog pojasa, što je utjecalo i na pojavu diversifikacije turističkog iskustva i doživljaja. Iako su klimatska i hedonistička zadovoljstva ostala glavni denominator suvremenog turizma, danas je postalo uobičajeno da turisti kupuju paket-aranžmane za egzotične i udaljene destinacije poput Australije ili Vijetnama, a u kontekstu doživljaja i iskustva suvremeni masovni turizam podrazumijeva nove oblike zabave od bungee skokova do skijanja i sl.

$S$ porastom količine slobodnog vremena, zarade i modnih trendova, sve više ljudi (180 milijuna Europljana) ide na odmor svake godine. Avanturistički duh sve je uočljiviji kod suvremenih turista, kao i veća potražnja za ljetovanjima koja su puna aktivnosti u prirodi, kulturnih i rekreativnih sadržaja. Primijećeno je da većina turista izbjegava destinacije $s$ narušenom životnom sredinom, kao i destinacije u kojima se odvijaju sukobi ili ratovi ili bi isti mogli uslijediti. Evidentan je pomak turista prema istočnom Sredozemlju i Srednjoj i Istočnoj Europi. Putovanje postaje sve brže i lakše te su i najudaljenije destinacije relativno lako dostupne. Putovanja i turizam predstavljaju veoma značajnu industriju i regionalno, nacionalno te globalno, a osim toga turizam potiče kulturu razumijevanja, uvažavanja i očuvanja mira. 


\section{TOTALNI TURIZAM}

Turističke atrakcije potiču ljude iz različitih krajeva svijeta da posjete neki turistički prostor i da u njemu privremeno borave. Ti dijelovi prostora artikulacijom i ponudom svojih sadržaja utječu na razvoj turističke ponude i razvoj turizma na nekoj destinaciji. Turizam kao industrija ili kulturna aktivnost usko je povezan $s$ prezentacijom nekog mjesta, s njegovom kulturnom, baštinom ili događajem i te se prezentacije odvijaju na pozornicama koje su stvorene u interakciji destinacija, tj. atraktivnih lokacija i zaposlenog osoblja i turista. Sama turistička industrija potpomognuta medijima i ponašanjem turista stvorila je takoreći te pozornice na kojima se odvija turizam. U tom procesu sudjeluju i mnogobrojni lokalni stanovnici od kojih ovisi sadašnjost i budućnost turizma. Bærenholdt i sur. (2004) smatraju da:

„Turizam posjeduje neke jedinstvene analogije $s$ dramaturškim izvedbama. Kao prvo, turističke prostore i vrijeme karakterizira njihova simbolička funkcija. Turizam se odvija u nekom određenom simboličkom okviru kojem se moguće prilagoditi i kojeg je moguće mijenjati. Kao drugo, turizam se obično odvija unutar omeđenih prostora; prostora koji su pri tome pretvoreni u 'dramaturške krajolike' odvijanja turizma. Kao treće, slično dramaturškim izvedbama velikim brojem tih ograničenih turističkih prostora upravljaju, reguliraju i kontroliraju ljudi i institucije koji djeluju kao pisci kazališnih komada, režiseri i scenska postava." (Bærenholdt i sur, 2004:51)

Turisti prihvaćaju njima namijenjenu ulogu turista na pozornici, koju im je namijenila turistička industrija, specijalizirani turistički mediji i radnje prethodnih turista. Uloga turista zahtijeva specifičan oblik odnosa prema okolini koji može biti okarakteriziran kao pustolovan i znatiželjan. Turisti traže zabavu, stimulaciju i dobrodošlicu, od njih se očekuje da kupuju suvenire i da fotografiraju ili da ih se vodi u razgledavanje i da im se priča o značajnim i interesantnim činjenicama. Žele upoznati lokalnu kulturu, ljude $i$ običaje. Posebno je važno doživjeti nešto autentično, posebno i novo. Turističko ponašanje naučeno je ponašanje koje se odvija u prikladnom kontekstu, međutim ono se i uči, nadograđuje i ponovno usvaja. Turističko ponašanje ovisi o kulturološkim razlikama koje se razlikuju od jedne do druge grupe turista. Kinezi su tako razvili njima svojstven stil turizma koji se sastoji od sakupljanja, kolekcioniranja što veće količine slika i doživljaja u što kraćem vremenu, u kojem nastoje posjetiti što više destinacija. Cjelodnevne posjete tematskim parkovima ili umjetničkim galerijama njima može izgledati potpuno strano i demotivirati ih jer ih pokreće potpuno različiti skup želja i motiva. Međutim, bez obzira koje su njihove sklonosti i koje je njihovo ponašanje, turisti predstavljaju ključan konstitutivni element svake turistički atraktivne lokacije i destinacije koje posjećuju.

Danas ulazimo u fazu totalnog turizma i svaki društveni fenomen postaje potencijalna i uzbudljiva turistički atraktivna lokacija i sadržaj turističkog proizvoda („mračni“ turizam, festivali, događaji, filmski turizam...). Sve je dozvoljeno, sve je moguće i sve postaje predmetom komercijalizacije i komodifikacije, uključujući i one najmarginalnije i najbanalnije pojave.

Međutim, nisu sva komercijalna dobra i usluge koje povećavaju stopu nacionalnog bruto proizvoda, objektivno dobra za pojedince, društvo i prirodu. Turizam je iskrivljen i 
izokrenut u korist relativno bogatih i moćnih, čiji interesi kontroliraju sudbinu velikog broja lokalnih zajednica i vrše invazivni simbolički utjecaj nad receptivnim kulturama i načinima života. Upozorenja o neuspješnom ili upitnom razvoju turizma u nerazvijenim zemljama i zemljama u razvoju, zapravo upozoravaju na neokolonijalno devastiranje kulture i ekonomije i nesadržajnost zapadne kulture koja dobar život i životni standard poistovjećuje s proizvodnjom i posjedovanjem.

U uvodnom dijelu ovog rada izričito je naglašena činjenica da u današnje vrijeme turističke destinacije nastoje kreirati jedinstvene identitete i turističke proizvode kako bi preživjele na sve konkurentnijem globalnom turističkom tržištu i da postoji tendencija komercijalizacije kulture, povijesnog naslijeđa i turističkih aktivnosti. Stoga su naredna poglavlja posvećena komodifikaciji kulture i komodifikaciji kulturne baštine u turizmu.

\section{KOMODIFIKACIJA KULTURE I AUTENTIČNOST TURISTIČKOG ISKUSTVA}

Mnoga mjesta, gradovi, regije ili države razvijaju opsežne programe „brendiranja“ kako bi se razlikovali jedni od drugih te naglasili svoju jedinstvenost na današnjem visoko konkurentnom tržištu. U izgradnji ili obnovi imidža turističke destinacije države koriste razna sredstva - od promotivnih kampanja u vlastitim državama s ciljem kvalitetnijeg odnosa prema gostima do isticanja slavnih stanovnika, kreiranja važnih događaja i stvaranja novih atraktivnih lokacija i događaja. Na sve konkurentnijem turističkom tržištu nadmoćnije će biti, ne bogatije, već kreativnije destinacije, odnosno destinacije koje će ponuditi originalniji i drukčiji doživljaj. Zemlje koje imaju prirodne ljepote, arheološke znamenitosti ili veliku kulturnu baštinu i povijest privući će „prirodne“ turiste. Ako ima premalo prirodnih atraktivnih lokacija, zemlja mora ulagati u marketing i kreiranje atraktivnih lokacija ili događanja, koji bi zatim privukli turiste, kao što, primjerice, radi Dubai. Novac treba potrošiti i na gradnju adekvatne infrastrukture, sigurnosti i usluge. Istodobno, ne treba zanemariti činjenicu da će turiste (još uvijek u najvećoj mjeri) privući odredišta za koja im se čini da im daju najbolju vrijednost za novac ili imaju najmanje mana.

Komodifikacija kulture uključuje i komodifikaciju ljudskih praksi. Aktivnosti koje su nekad bile dio svakodnevnog života lokalne zajednice pretvaraju se u komodificirane aktivnosti, susrete i suvenire namijenjene turistima. Glavna je pretpostavka da turizam i prisutnost turista nerijetko rezultiraju gubitkom izvorne, prave, autohtone kulture na čije mjesto dolaze trivijalna, komodificirana događanja, proizvodi i iskustva koja degradiraju i proizvođača i potrošača. Čest je slučaj da se za potrebe turističke industrije turistima prezentiraju starinski zanati i ostali segmenti tradicije i tradicijskog života neke zajednice, koje lokalno stanovništvo već odavno ne prakticira. Ovakva uprizorenja na upitan način govore o vremenu koje je prošlo, spomenici i povijesna građa služe kao dokaz izvornosti u komercijalne svrhe, a sami prikazi često su zbrkani. Petterson i Viken (prema Hannam i Knox, 2010:46) npr. pišu o komodifikaciji pojedinih aspekata 
kulture naroda Sámi u Finskoj. Ova etnička grupa, prije poznata kao Laponci, broji 70.000 pripadnika koji žive raštrkani na površini od oko milijun i sto tisuća četvornih kilometara na tlu Norveške, Švedske, Finske i Rusije. Njihova kultura komodificirana je kao dio muzejske zbirke, u cilju prodaje rukotvorina, izvedbi tradicijskih običaja i u kontekstu njihove osobne pojavnosti. Proizvedene rukotvorine značajno su prerađene za turistička tržišta, kao i suveniri. Sobova koža više se ne koristi u praktične, već u ukrasne svrhe, a meso soba priprema se tako da posjetiteljima bude jestivo. Slično se događa i $s$ aboridžinskom zajednicom u Australiji, za koju postoji toliko veliki interes da je čak 2006. Lonely Planet publicirao svoj vodič pod imenom Going Bush, u kojem navodi da se mnogi predmeti proizvode isključivo za prodaju na turističkom tržištu. Sličan se proces odvija i kod nas, u Istri. Iz ovih je primjera prilično jasno da se tu više ne radi o izvornim i netaknutim kulturama. U općoj merkantilizaciji stvarnosti, sve se turistički vrednuje i prodaje. Kultura je sada institucionalizirana, kategorizirana i spremna za uporabu, a tradicije se uprizoruju i oživljavaju (Hannam i Knox, 2010).

Američki antropolog Dean MacCannell u svom dijelu The Tourist (1976), izražava zabrinutost da bi turizam komercijalizacijom i komodifikacijom kulture i načina života mogao uništiti autentičnost destinacija. Sve veći utjecaj turističke industrije, sve bolji uvjeti putovanja i proliferacija destinacija, neminovno su utjecali na pojavu i razvoj brojnih rasprava o utjecaju turizma na autentičnost pojedinih kultura. Diskusije o autentičnosti u turizmu započele su s radovima D. J. Boorstina (1962), koji je i jedan od prvih kritičara masovnog turizma. Boorstin smatra da masovni turizam utječe na stvaranje homogenizacije i standardizacije turističkog iskustva kroz komodifikaciju kulture, $s$ kasnije doživljenim turističkim iskustvom temeljenim na pseudodogađaju. On smatra da umjesto autentičnosti turist više voli svoja malograđanska očekivanja. Svojim drukčijim i puno optimističnijim pristupom MacCannell (1976) suprotstavlja se Boorstinu, tvrdeći baš suprotno, odnosno da turizam omogućava turistima ostvarivanje autentičnih događaja. MacCannell smatra da je turist moderni sekularni hodočasnik u potrazi za autentičnošću drugih mjesta i kultura. To je autentičnost koju je nemoguće iskusiti u otuđenom modernom društvu i autentičnost kao nadomjestak za njegov površan život koji vodi u domicilnoj sredini. Uglavnom je zaokupljen frustracijama probijanja turista kroz uprizorenu autentičnost kakvu lokalno stanovništvo i turistička industrija nude u turistički razvijenim sredinama. Rasprave o autentičnosti u turizmu obilježile su cjelokupnu teoriju o turizmu u proteklih 40-tak godina. $U$ fokusu je interesa utjecaj turizma na autentičnost turističkog iskustva, kulture domaćina, odnosa između domaćina i gosta, proizvodnje kulturnih objekata i konzumacije događaja. Glavna je pretpostavka da turizam i prisutnost turista utječu na gubitak izvorne, stvarne kulture, koja je zamijenjena trivijalnim, komodificiranim događajima, proizvodima i doživljajima koji osiromašuju i proizvođača i potrošača. Naravno teško je definirati što to znači autentično, izvorno i stvarno jer su to relativni termini koji u različitim kulturama mogu imati različito značenje. Wang (1999) je u svom istraživanju turističkog iskustva napravio jasnu distinkciju između autentičnosti usmjerene k objektu, konstruirane autentičnosti i egzistencijalne autentičnosti usmjerene $\mathrm{k}$ aktivnosti. 
Objektivna autentičnost odnosi se na autentičnost originalnih objekata / predmeta, pri čemu se zadovoljava kognitivna (spoznajna) komponenta kod posjetitelja. Objektivna autentičnost pretpostavlja mogućnost postojanja izvornih turističkih iskustava i proizvoda, ali ih je u suvremenom društvu veoma teško pronaći. Radi se o objektima koji su izrađeni od onih materijala koji se smatraju autentičnim i koje su izradili autohtoni zanatlije i obrtnici, kao i o događajima i ritualima za koje se smatra da potječu i da su izraz tradicionalnih i izvornih kultura. Diskusija između Boorstina i MacCannella povezana je s objektivnom autentičnošću i u tom kontekstu turističko je iskustvo razmatrano ili kao autentično ili kao neautentično. Prema MacCannellu (1976), do autentičnog iskustva dolazi kada turist vidi stvaran objekt umjesto onoga koji je insceniran za turističko konzumiranje. Jedan od najznačajnijih pojmova, kada govorimo o autentičnosti, je staged authenticity, odnosno inscenirana, namještena ili uprizorena autentičnost. MacCanell također ističe da kod inscenirane autentičnosti autohtono stanovništvo nudi na prodaju svoju kulturu (tradicijska muzika i ples izvučeni iz konteksta i uprizoreni za zabavu turista), uključujući i sebe, kako bi stvorili primamljiv turistički proizvod. On smatra da primitivne i udaljene zajednice nemaju izgrađen koncept autentičnosti i stoga još nisu razvili sustav prednjih i stražnjih područja kako bi zaštitili svoju privatnost. MacCannell se oslanja na Goffmanovu podjelu prostora za prihvat turista, odnosno na prednje i stražnje planove. Prednji plan je točka susreta domaćina i gostiju, odnosno klijenta i uslužnog osoblja, a zadnji je plan mjesto gdje se domaćini pripremaju za izlazak pred goste. Gosti često smatraju da je autentično upravo ono što je iza, prostor gdje domaćini borave, na čemu kuhaju, što svakodnevno oblače i svjesni su umjetne autentičnosti koja im se nudi u prednjem planu. Dakle, stvarni život odvija se iza scene, u pozadini, dok je na sceni turizam reduciran na skup umjetnih, plastičnih, neautentičnih značenja koja nemaju nikakav društveni život u pozadini osim onog dekoracijskog i ima negativan utjecaj na kulturu i turizam.

Wangovo (1999) viđenje autentičnosti nije crno bijelo, već uključuje i puno širi spektar značenja i dok npr. neki stručnjaci mogu procijeniti određeno iskustvo kao neautentično, neki turisti će to isto iskustvo smatrati autentičnim. To nas dovodi do koncepta konstruirane autentičnosti, odnosno do socijalno konstruirane autentičnosti. U toj perspektivi autentičnost nije neraskidivo vezana s objektom, već je zavisna o iskustvu i interpretaciji autentičnosti različitih tipova turista, što znači da je to društvena ili osobna konstrukcija koja zavisi od imaginacije, očekivanja, preferencije, vjerovanja, utjecaja i sličnog. Konstruirana autentičnost nije statičan koncept, nego je podložna promjenama i rekonceptualizacijama, što nije samo osobna konstrukcija, nego je i društveno stvorena i postoji veliki broj navodno drevnih tradicija koje su kreirane za potrebe suvremenog društva (turizma) i veoma su brzo postale prihvaćene kao dio zajedničke ili nacionalne povijesti. U tu kategoriju najčešće spadaju razne krunidbene ceremonije, kraljevska vjenčanja, nacionalne himne i zastave kao simboli nacionalne pripadnosti i patriotizma, koje se drži autentičnima i iz perspektive posjetitelja i iz perspektive zajednice. U kreiranju autentičnosti, odnosno atraktivnih verzija realnosti, sudjeluje turistička industrija i s njom povezani mediji kao dio proizvoda koji se prezentira posjetiteljima i koje turisti prihvaćaju kao dio paket-aranžmana. 
Za razliku od objektivne i konstruirane (simboličke) autentičnosti, koje problematiziraju autentičnost posjećenog objekta, egzistencijalnu autentičnost određuje egzistencijalni doživljaj. Ovaj doživljaj uključuje osobne ili intersubjektivne osjećaje, aktivirane oslobađajućim procesom turističke aktivnosti. Egzistencijalna je autentičnost zapravo atribut koji označava da je osoba istinita prema sebi, odnosno istinita prema svojoj suštinskoj prirodi. Veliki broj današnjih turista za vrijeme svog putovanja teže samoaktualizaciji i izražavanju svog kreativnog potencijala. Oni traže suptilan, nenametljiv trenutak koji će u njima pokrenuti jedinstven doživljaj i oslobađanje. Taj trenutak mora biti stvaralački čin, u bilo kojem obliku (ples, slikarske radionice, sviranje, pravljenje rukotvorina i slično), a koji zahtjeva inventivnost, imaginaciju i originalnost. Upravo je egzistencijalna autentičnost središnja tema kada se govori o razumijevanju turističke kulture i konceptualizaciji turista za čiju je kvalitetu turističkog iskustva i razinu samoaktualizacije ključna interakcija koja predstavlja polazišnu osnovu za mogućnosti razvoja turističkih marketinških niša poput: kreativnog turizma, pustolovnog turizma, ekološkog turizma, turizma naslijeđa itd., koji za razliku od masovnog turizma nude drukčiju vrstu turističkog iskustva.

\section{KOMODIFIKACIJA KULTURNE BAŠTINE U TURIZMU}

Doživljavati „nešto“ postalo je i cilj i zadatak turističkog putovanja koje se ne svodi samo na odmor, a stvaranje tog „nečeg“ postaje motivacijski imperativ profesionalaca u turističkoj industriji. Graham i sur. (2000) prave razliku između termina prošlost, povijest i baština. Prošlost se odnosi na sve ono što se ikada dogodilo, povijest se odnosi na nastojanja današnjih povjesničara da objasne određene aspekte prošlosti, a baština se odnosi na suvremenu interpretaciju i reprezentaciju prošlosti. Međutim sa razvojem industrije naslijeđa koncept baštine sve se više povezuje sa komercijalizacijom i komodifikacijom prošlosti. Kako bi neka destinacija bila poželjna turistima ona pokušava održati svoju privlačnost kroz komercijalizaciju prošlosti, tako da turistima ponudi slike onoga što oni žele doživjeti, jer turist na odredištu konzumira stvorene predodžbe o odredištu, a ne svakodnevni život. Baština je višestruk pojam i obuhvaća sve od povijesnih artefakata, preko zgrada i krajolika do priča iz povijesti. Tipične turističke atraktivne lokacije koje pripadaju baštini dijele se na: izgrađene atraktivne lokacije (spomenici, povijesne zgrade, arhitektura, arheološka nalazišta), prirodne atraktivne lokacije (nacionalni parkovi, krajolici, obala, špilje), vjerske atraktivne lokacije (crkve, katedrale, hramovi, džamije, sinagoge, mjesta i gradovi hodočašća), industrijsko naslijeđe (rudnici, tvornice, industrijski krajolici), literarno naslijeđe (kuće i rodni gradovi poznatih pisaca), umjetničko naslijeđe (krajolici i okruženja koji nadahnjuju umjetnike), različite kulturne atrakcije (tradicionalni festivali, događaji, ples i narodna glazba). Koncept nematerijalne baštine postaje sve važniji i zato je UNESCO 2003. usvojio Konvenciju o zaštiti nematerijalne kulturne baštine. Pod pojmom nematerijalne kulturne baštine podrazumijevaju se izrazi, umijeća, znanja, predstavljanja - kao i instrumenti, predmeti i kulturni prostori koje društva, skupine, katkad i pojedinci, prepoznaju kao dio vlastite kulturne baštine. 
Navedeni oblici nematerijalne kulturne baštine manifestiraju se u narodnom jeziku i usmenoj književnosti, izvedbenoj umjetnosti koja podrazumijeva muziku i ples, narodnim običajima i znanjima vezanim za tradicionalne vještine i rukotvorine.

Broj posjetitelja na nekim mjestima svjetske baštine, pogotovo onima koja su uvrštena na UNESCO-ov popis mjesta svjetske baštine, počinje predstavljati ozbiljan problem. Preveliki broj turista pretvara te lokacije u mjesta masovnog turizma i iako UNESCO zagovara njihovu dostupnost što većem broju ljudi, postalo je veoma teško uspostaviti ravnotežu između konzervacije i boravka prevelikog broja ljudi na tim prostorima. To pogotovo dolazi do izražaja u slučajevima kada je lokalno stanovništvo dio krajolika (npr. u povijesnim gradovima ili kulturnim krajolicima). Mjesta na listi svjetske baštine međusobno se razlikuju i stoga je neizvedivo njihovo upravljanje učiniti standardiziranim. Planovi upravljanja moraju voditi računa o specifičnostima svakog mjesta ponaosob. Sudbina atrakcija i mjesta koja nisu uvrštena na listu svjetske baštine ovisi o njihovom vlasniku, njegovim financijskim mogućnostima i filozofiji upravljanja.

Prekomjeran broj posjetitelja može dovesti do akulturacije ili trajne promjene u autohtonoj kulturi. Drugim riječima, domicilno stanovništvo počinje prilagođavati svoje djelovanje, aktivnosti i cjelokupnu životnu praksu interesima turista ili postaje podložno utjecaju turista i njihovim obrascima ponašanja. Radi se o problemu s kojim se (ne) znaju nositi ni u Dubrovniku, Puli ili Poreču.

Ovdje se međutim ne radi samo o zanemarivanju i neadekvatnoj zaštiti kulturne baštine autohtonog stanovništva ili plemenskih grupa. Samuel (1994) smatra da baština odražava dominantnu estetiku i javni ukus, odnosno ono što se u društvu cijeni u datom vremenu. To znači da je ona sama po sebi pristrana i elitistička i da tradicionalno odražava ukuse i sklonosti bijele europske muške srednje klase. Zahvaljujući utjecaju postmoderne misli i kulturne politike učinjen je veliki korak prema valorizaciji baštine manjinskih skupina i etničkih grupa u društvu. Čak je i društvena povijest običnih ljudi bila uvijek u drugom planu u odnosu na kraljevsku ili vojnu povijest, kojom su uglavnom dominirali muškarci, a manje žene. Međutim, danas se situacija mijenja i mjesta baštine i muzeji sve se više okreću baštini šireg sloja ljudi. Postmodernom pluralizacijom povijesti i njezinom interpretacijom i reprezentacijom došlo je do sve većeg uvažavanja industrijske, zemljoradničke i popularne narodne baštine, a time i do demokratizacije cijelog tog procesa. Postoje i različiti stavovi i diskusije o načinu interpretacije kulturne baštine.Neki teoretičari (Swarbrooke, 1999) smatraju da interpretacija baštine ima ulogu sanitizacije, glorifikacije i prikaza jedne mekše verzije prošlosti, u cilju izbjegavanja mogućih konflikta i kontroverza. To je pogotovo uobičajeno u turizmu. Turiste ne zanimaju stvarne činjenice ili historiografska stvarnost, oni su u potrazi za iskustvom i stoga je glavni cilj turističke industrije zabaviti i animirati, a ne šokirati i prestraviti posjetitelje. Naravno, postoje i oni teoretičari (Ashworth i Tunbridge, 2000) koji tvrde upravo suprotno i koji smatraju da je baštinu nužno prezentirati u svjetlu stvarnih činjenica, koje će emocionalno šokirati i ganuti posjetitelje.

Postoje različiti načini na koje se baština može iskoristiti u turističke svrhe. Jedan od primjera uključuje i „živu baštinu“, odnosno uključivanje kostimiranih glumaca u in- 
terpretaciju i prezentaciju nekih povijesnih događaja. Brojni su takvi primjeri evidentni i u različitim krajevima Republike Hrvatske. Iako povjesničari i konzervatori često ističu svoju sumnju u vjerodostojnost takvih uprizorenja prošlosti, ovaj je oblik prezentacije veoma popularan među publikom i pruža joj mogućnost aktivnog sudjelovanja u tim manifestacijama i događajima.

U suvremenom turizmu, turizam baštine predstavlja jedan od glavnih svjetskih turističkih sektora u porastu i osim tradicijskih procesa i praksi uključuje i široki spektar ljudi i njihovih kultura.

S tolikim brojem atraktivnih lokacija i događaja upravljanje turizmom baštine može biti veoma zahtjevan i složen proces. Ako se turizam razvija i distribuira na lokalnom nivou i u suradnji s lokalnim zajednicama, puno će se lakše oduprijeti globalnim imperativima kapitalne intenzifikacije. Lokalne zajednice zadržavaju vlasništvo i kontrolu nad turističkim resursima i pružaju usluge i proizvode turistima, bez potrebe za velikom količinom početnog kapitala i sofisticirane infrastrukture. Turistička destinacije pretvara se u dinamični interaktivni prostor sposoban prilagoditi svoju kulturu i način života zahtjevima i načelima kulturne i ekonomske održivosti. O podjeli moći između i unutar zajednica, poduzetnika u turizmu, posredničkih organizacija i samih turista potrebno je voditi računa prilikom planiranja i razvoja turizma. Što se tiče razvoja turizma u lokalnim zajednicama nerealno je očekivati da inicijatori pozitivnih promjena budu međunarodni, nacionalni ili regionalni čimbenici jer je prevelika moć i utjecaj uloženih interesa. Prava inicijativa trebala bi krenuti odozdo, s lokalnog nivoa, tamo gdje postoji i najveća potreba za promjenama. $U$ tom procesu svakako trebaju sudjelovati lokalni stanovnici, a ne samo turistički djelatnici i vlasnici hotela.

Svako turističko područje, lokalitet ili destinacija bez obzira na svoje prostorne granice, ulazi u turistički razvoj sa svojevrsnim rizikom moguće saturacije. U ranim danima masovnog turizma nije se previše poklanjalo pažnje planiranju turističkog razvoja i destinacije su se razvijale stihijski i u skladu s potražnjom. U takvim se uvjetima turističkog razvitka nije previše vodilo računa o dugotrajnim posljedicama niti o ekonomskim, prostornim i sociokulturološkim potrebama lokalnih zajednica i njihovog stanovništva i došlo je do pojave negativnih posljedica i kasnije stagnacije, propadanja i neatraktivnosti pojedinih destinacija (Tablica 1). Velikom broju takvih mjesta u svijetu zbog prevelikog broja turista koji ih posjećuju prijeti devastacija, tako da su problemi konzervacije i upravljanja tim resursima ključne teme kojima se ovaj podsektor kulturnog turizma bavi u proteklih nekoliko godina. Glavni je izazov održavanje ravnoteže između konzervacije i upravljanja posjetiteljima. Konzervatori su u pravilu uvijek spremni izdati dozvolu za obnovu baštine, ali nisu uvijek tako blagonakloni prema pretjeranom broju posjetitelja ili pretjeranom turističkom razvoju. Upravljanje turizmom u urbanim sredinama zahtijeva integrirani pristup. Uspješno planiranje mora biti usmjereno na rješavanje sukoba interesa između urbanih planera, osoba zaduženih za turistički razvoj, konzervatora i lokalnog stanovništva. U povijesnim gradovima obitava životno i radno aktivno stanovništvo i stoga je nedopustivo da se te lokacije zbog turizma ili industrije naslijeđa pretvaraju u muzeje ili fosilizirane povijesne atrakcije na otvorenom. 
Tablica 1. Tipični negativni učinci razvoja turizma

\begin{tabular}{|c|c|c|}
\hline Ekonomski učinci & Prostorni učinci & Sociokulturološki učinci \\
\hline $\begin{array}{l}\text { Prevelika ekonomska } \\
\text { ovisnost o turizmu }\end{array}$ & Uništavanje vegetacije & $\begin{array}{l}\text { Konflikti i nesporazumi } \\
\text { između pojedinih kultura }\end{array}$ \\
\hline $\begin{array}{l}\text { Turizam pod kontrolom } \\
\text { velikog broja stranih } \\
\text { rukovodilaca i investitora }\end{array}$ & $\begin{array}{l}\text { Ekološki poremećaj } \\
\text { Zagađenje vode } \\
\text { Zagađenje zraka } \\
\text { Arhitektonsko } \\
\text { zagađenje }\end{array}$ & $\begin{array}{l}\text { Osjećaj eksploatacije i } \\
\text { podređenosti lokalnog } \\
\text { stanovništva } \\
\text { Prostorna prenapučenost i } \\
\text { stvaranje turističkih enklava }\end{array}$ \\
\hline $\begin{array}{l}\text { Turizam kao novi oblik } \\
\text { imperijalizma }\end{array}$ & $\begin{array}{l}\text { Problemi s odlaganjem } \\
\text { smeća }\end{array}$ & Socijalni problemi \\
\hline $\begin{array}{l}\text { Preveliki naglasak na } \\
\text { turizmu na štetu drugih } \\
\text { industrija }\end{array}$ & $\begin{array}{l}\text { Oštećenja arheoloških i } \\
\text { povijesnih lokacija }\end{array}$ & $\begin{array}{l}\text { Lokalno stanovništvo koje } \\
\text { imitira ponašanje turista (tzv. } \\
\text { demonstracijski učinak) }\end{array}$ \\
\hline $\begin{array}{l}\text { Stvaranje nestabilnih } \\
\text { i neadekvatnih uvjeta } \\
\text { zaposlenja za lokalno } \\
\text { stanovništvo }\end{array}$ & $\begin{array}{l}\text { Prenatrpanost } \\
\text { Problemi s korištenjem } \\
\text { zemljišta }\end{array}$ & $\begin{array}{l}\text { Eventualna erozija društvene } \\
\text { strukture } \\
\text { Pretjerana komercijalizacija } \\
\text { kulture i gubitak autentičnosti }\end{array}$ \\
\hline
\end{tabular}

Izvor: Smith i sur. (2010:124).

Adekvatno i pravovremeno organiziranje, planiranje i upravljanje razvojem turizma na lokalnoj razini, koje je često nedovoljno zastupljeno i zanemareno na uštrb regionalnog i nacionalnog planiranja, pridonosi kvalitetnijem razvoju turizma i izbjegavanju neželjenih posljedica u lokalnoj zajednici.

Takvo planiranje na lokalnoj razini obuhvaća brigu za prostorno, privredno i sociokulturološko planiranje i organiziranje elemenata ponude na način da njihov razvoj bude kompatibilan s ostalim aktivnostima i brigu za postizanjem održivog razvoja, kako na lokalnoj razini tako i u širem okruženju. Prilikom aktivnog uključivanja lokalne zajednice u planiranje turističkog razvoja i kontrolu proizvoda koji sačinjavaju turističko iskustvo presudnu ulogu ima lokalna uprava i samouprava kao predstavnik javnog sektora i kao glavni pokretač planiranja i razvoja turizma u lokalnoj zajednici. Tamo gdje razvoj i planiranje nisu u skladu s lokalnim željama i mogućnostima, otpor i neprijateljstvo mogu uništiti ukupni proces turističkog razvoja neke destinacije. Pravovremeno i kvalitetno planiranje turističkog razvoja utječe na stvaranje pozitivnih učinaka na privrednom, prostornom i sociokulturološkom planu (Tablica 2).

Potrebno je za kraj istaknuti kako ne postoji jedinstveno pravilo o planiranju turističkog razvoja, koje bi bilo primjenljivo na sve destinacije i stoga je planove potrebno prilagoditi pojedinostima i specifičnostima svake pojedine destinacije. 
Tablica 2. Tipični pozitivni učinci razvoja turizma

\begin{tabular}{|l|l|l|}
\hline \multicolumn{1}{|c|}{ Ekonomski učinci } & \multicolumn{1}{|c|}{ Prostorni učinci } & \multicolumn{1}{|c|}{ Sociokulturološki učinci } \\
\hline $\begin{array}{l}\text { Otvaranje radnih } \\
\text { mjesta }\end{array}$ & Očuvanje prirodnih područja & $\begin{array}{l}\text { Stimulacija za očuvanje } \\
\text { kulturnog naslijeda }\end{array}$ \\
\hline $\begin{array}{l}\text { Koristi od strane } \\
\text { valute }\end{array}$ & $\begin{array}{l}\text { Očuvanje povijesnih i } \\
\text { kulturnih lokaliteta }\end{array}$ & Revitalizacija tradicije i običaja \\
\hline $\begin{array}{l}\text { Poboljšani uvjeti } \\
\text { života }\end{array}$ & $\begin{array}{l}\text { Inicijativa za čišćenje } \\
\text { lokanog područja }\end{array}$ & Razvoj kulturnih sadržaja \\
\hline $\begin{array}{l}\text { Ekspanzija ostalih } \\
\text { ekonomskih sektora }\end{array}$ & $\begin{array}{l}\text { Poboljšanje lokalne } \\
\text { infrastrukture } \\
\text { Povećanje lokalne svijesti o } \\
\text { ekološkim problemima }\end{array}$ & $\begin{array}{l}\text { Osjećaj ponosa prema vlastitoj } \\
\text { kulturi } \\
\text { Mogućnosti za veću } \\
\text { emancipaciju žena }\end{array}$ \\
\hline
\end{tabular}

Izvor: Smith i sur. (2010:126).

Rasprava o turizmu i razvoju zahtjeva preispitivanje uloge države, vlade i njezine politike, te njihovu povezanost $s$ mnogim aspektima turističkog sustava. Moć države ostvaruje se kroz različite institucije na različitim razinama, a njihova politika izravno ili neizravno utječe na turistički razvoj i na sredine koje se nalaze unutar granica nacionalne države. Još uvijek ne postoji nešto što bi se moglo nazvati savršena destinacija, ali pažljivim planiranjem turističkog razvoja moguće se približiti načelima stvaranja etičkog i održivog turizma.

\section{ZAKLJUČAK}

Masovni turizam ostaje dominantan oblik turističkog razvoja svugdje u svijetu. $\mathrm{U}$ ovom kontekstu turizam mnogo više asocira na besciljno putovanje u druge zemlje, metež, gužvu, a manje ima konotativno značenje u smislu širenja vidika, prijateljstva, otkrivanja, autentičnosti i samoaktualizacije. Turizam je danas pretvoren u industriju odmora koja podilazi masovnom srednjem sloju nedefiniranog ukusa. Masovni turist nosi ulogu koju mu je namijenila turistička industrija. On je tzv. totalni turist i na tako masovno koncipiranom odmoru koji provodi izvan domicila onemogućen mu je razvoj osobnosti i osobnog integriteta. On je i dehumaniziran i često se ne doživljava kao subjekt, nego kao broj.

Zbog svoje masovnosti i ovakvog vrijednosnog sistema na kojem počiva, turizam će se teško oduprijeti komercijalno-potrošačkom duhu na koji se cjelokupna masovna kultura i turizam oslanjaju. Turizam se tako mjeri prijeđenim kilometrima, satima letenja, noćenjima, hotelima i pansionima i pretvara se u svojevrsni bijeg od svijeta rada, iz banalne svakodnevnice u obećani svijet godišnjih odmora, svijet mašte koji je izgrađen tako dobro da bi što vjernije dočarao iluziju sreće. Općenito govoreći, ljudi odabiru one aktivnosti u turističkoj dokolici koje se uklapaju u njihov svjetonazor i životni stil, koji su pak ovisni o dobi, spolu, klasnoj pripadnosti, visini obrazovanja, bračnom statusu i visini 
primanja. Determinirajuće varijable u tom kontekstu definitivno su razina obrazovanja i razina prihoda. Danas je odlazak na odmor postao način i smisao života suvremene civilizacije pri čemu turizam jednim velikim dijelom funkcionira kao dokazivanje vlastitog statusa $\mathrm{u}$ društvu, kao pozicijsko dobro. Prema podacima Booking.com-a za 2019. (BookingSuite, 2019) više od polovice turista želi posjetiti destinaciju na kojoj nitko drugi nije bio. Odabirom destinacije, načina odmora i izborom aktivnosti na odmoru turisti šalju poruku društvu o sebi, što je dio stvaranja vlastitog identiteta. Danas, slobodno vrijeme, a tako i turistička dokolica postali su područje oblikovanja vlastitog identiteta, pri čemu karijera i profesija sve više gube na važnosti u odnosu na potrošačke navike. Postajemo ono što jesmo načinom na koji provodimo dokolicu, vrstom auta koji vozimo, izborom destinacija u koje putujemo. $U$ tom kontekstu putovanje tj. turizam predstavlja način socijalne diferencijacije i distinkcije pripadnika viših od nižih klasa. Kada govorimo o razvoju turizma danas prisutan je svojevrsni paradoks, a to je činjenica da s jedne strane globalizacija (čija su dva najvažnija aspekta tehnološki razvoj i integracije ekonomije u globalnu ekonomiju s globalnim tržištem) pridonosi daljnjem širenju trenda masovnog turizma i učvršćuje efekte deregulacije avioprijevoza, paket-aranžmana, masovne proizvodnje usluga, dok je $s$ druge strane omogućila i veću fleksibilnost za individualne potrošače i pridonijela rastu i stvaranju personaliziranih i prilagođenih proizvoda i usluga bez kojih nema razvoja novih oblika turizama. Dakle, turizam je najvećim svojim dijelom i dalje konvencionalan, masovan i tako će to i dalje ostati, iako se trendovi u provođenju turističke dokolice i odabiru destinacija neprestano mijenjaju. Sada, međutim, ne znamo kakav će turizam biti u budućnosti, te što će na to presudno utjecati? Turistima je potrebno prenijeti emociju i zaokupiti njihova osjetila i zato je potrebno raditi na promjeni svijesti, mentaliteta. Autentičnost nekog mjesta čini atmosfera, ozračje. Ljudi ne dolaze zbog smještajnih kapaciteta, nego zbog ljepote prirode i kvalitete sadržaja. Prema svim relevantnim istraživanjima (Marušić, i sur., 2018) kulturna baština nije pri vrhu liste motiva turista prilikom posjete nekoj destinaciji u Republici Hrvatskoj i kod nas gotovo da i nema turista koji bi se mogao nazvati namjerni kulturni turist. O kulturnoj ponudi i sadržajima turisti saznaju tek po dolasku u destinaciju. Hrvatska će i dalje biti destinacija sunca i mora i od toga ne treba bježati. Ali, uz ekonomsku, turizam mora imati sadržajnu komponentu, onu koja će ljudima omogućiti produktivno, korisno, kulturno, sadržajno odmaranje, nešto što će im omogućiti afirmaciju njihovih stvaralačkih sposobnosti i interesa i unaprijediti ličnost. Zato je potrebno razvijati selektivne oblike turizma, tzv. turizam specijalnog interesa da bismo obogatili i oplemenili masovni turizam, proširili strukturu i produžili vremenski ciklus ponude.

Specifični oblici turizma potiču i omogućavaju upoznavanje drugih sredina i intenzivno praćenje aktualnih zbivanja, stjecanje novih znanja i usvajanje kulturnih vrijednosti, pa i na taj način pomažu čovjeku da zauzme jedan određeniji stav prema sebi i drugima, te iz pasivnog stava pređe u aktivniji odnos. Specifične oblike turizma Novelli (2005) definira kao oblik turizma koji uključuje turiste koji u skladu sa svojim specifičnim motivacijama odabiru i odlaze na određenu vrstu odmora ili putovanja i čiji je nivo zadovoljstva određen iskustvom koje proizlazi iz odabrane turističke aktivnosti. Turisti specijalnih interesa sve više postaju značajan segment turističkog tržišta namijenjenog onim turisti- 
ma koji za vrijeme odmora žele zadovoljiti i svoje specifične interese i tako uvećati svoj kulturni kapital. Specifični oblici turizma pojavljuju se kao odraz nove vrijednosti koja uključuje povećanu važnost aktivnosti na otvorenom prostoru, svijest o ekološkim problemima, edukativno napredovanje, estetsko prosuđivanje i napredak društva i samog pojedinca (Genov, 2008). Za razliku od masovnog turizma koji se odvija u poznatom i predvidljivom okruženju, turizam specijalnih interesa zasniva se na novim destinacijama ili aktivnostima koje udovoljavaju potrebama promjenljivog tržišta. Takav koncept i organizacija odmora i putovanja idealna je za susret i upoznavanje $s$ istomišljenicima. Turisti specijalnih interesa zaokupljeni su potragom za mogućnostima osobnog i međuljudskog razvoja i napretka, a ne s mogućnostima bijega iz ljudskog i međuljudskog okruženja. To znači da turizam specijalnih interesa nije povezan s motivima bijega (eskapizma) i relaksacije nego s aktivnim samorazvojem i stjecanjem novih iskustava.

Turizam specijalnih interesa puno je održiviji i etičniji od masovnog turizma, prvenstveno zbog manjih grupa turista, činjenice da se radi o obrazovanijim i iskusnijim skupinama i činjenici da je glavni razlog putovanja potraga za autentičnim prirodnim ili kulturnim iskustvima i doživljajima. Turizam specijalnih interesa pomiče turističke granice i dovodi turizam u područja izvan turističkih enklava. Međutim, takav razvoj iziskuje kvalitetno i odgovorno upravljanje, u suprotnom može rezultirati i negativnim posljedicama po lokalnu zajednicu i turiste. Neki oblici, poput religijskog turizma, „mračnog" turizma, ili u ovom slučaju turizma naslijeđa zahtijevaju dobro i senzibilno upravljanje i kvalitetnu interpretaciju na licu mjesta. Turizam specijalnih interesa karakterizira kvalitativan odmak u odnosu na masovni turizam čime se promoviraju socijalno pravedni oblici turizma, koji zadovoljavaju potrebe turista da se angažiraju u oblicima ponašanja koja, u najboljem slučaju, mogu biti opravdana kao društveno odgovorna. Postojeće masovne i uniformirane vrste turizma oplemenjuju se novim i kvalitetnijim sadržajima, a s druge strane rastu i razvijaju se i nove vrste turizma koje zahvaljujući svojoj izvornosti i raznolikosti obogaćuju njegov sadržaj. Na taj se način značajno umanjuju svi mogući negativni efekti i uvećavaju pozitivni sociokulturološki, prostorno-ekološki i ekonomski elementi i učinci. 


\section{LITERATURA}

Ashworth, G. i Tunbridge, H. (2000). The Tourist-Historic City. Oxford: Pergamon.

Baranowski, S. (2004). Strength Through Joy: Consumerism and Mass Tourism in the Third Reich. Cambridge: Cambridge University Press.

Bærenholdt, O., Haldrup, M., Larsen, J. i Urry, J. (2004). Performing Tourist Places. Aldershot: Ashgatr.

BookingSuite (2019). Your guide to 2019's top travel trends. URL: https://suite.booking. com/resources/publications/2019-travel-trends- guide/?utm_source=content\&utm_ medium=guide\&utm_content=2019_Q1_2019TrendsG uide_HR\&utm_campaign=2019_Q1_GLO_2019Trends (20.02.2019.)

Boorstin, D. J. (1962). The Image: A guide to Pseudo-Eventsin America. New York: Vintage Books.

Bourdieu, P. (1984). Distinction: A social critique of judgement of taste. London: Rutledge and Kegan Paul.

Crick, M. (1989). Representations of International Tourism in the Social Sciences. Annual Review of Anthropology, 18: 307-344.

Čavlek, N. (1998). Turoperatori i svjetski turizam. Zagreb: Golden Marketing.

Genov, G. (2008). Turizam posebnih interesa - selektivni oblici turizma, Beograd: Čugura print.

Graham, B., Ashworth, G. J. i Tunbridge, J. E. (2000). A geography of Heritage: Power, Culture and Economy. London: Arnold.

Hannam, K. i Knox. D. (2010). Understanding Tourism. London: Sage.

Lash, S. i Urry, J. (1993). Economies of Signs and Space. London: Sage.

MacCannell, D. (1976). The Tourist: A new theory of the leisure class. London: University of California Press.

Marušić, Z., Čorak, S. i Sever, I. (2018). Ljeto Tomas 2017. - Stavovi i potrošnja turista u Hrvatskoj. Zagreb: Institut za turizam.

Novelli, M. (2005). Niche Tourism: Contemporary Issues, Trends and Cases. Oxford: Butterworth-Heinemann.

Samuel, R. (1994). Theatres of Memory. London: Verso.

Smith, M., Macleod, N. i Hart Robertson, M. (2010). Key Concepts in Tourist Studies. London: Sage.

Swarbrooke, J. (1999). SustainableTourism Management. New York, CABI Publishing. Štifanić, M. (2002). Nastanak i razvoj sociologije turizma. Društvena istraživanja: časopis za opća druśtvena pitanja, 11(6/62): 859-877.

Wang, N. (1999). Rethinking authenticity in tourism experience. Annals of tourism research, 26(2): 349-370. 


\title{
COMMERCIALIZATION OF CULTURAL HERITAGE IN TOURISM
}

\author{
Mauro Dujmović
}

\begin{abstract}
Summary
Tourism has become a consumer commodity in postmodern society. History, time and space as aspects of culture are being transformed into market commodities. At the same time, the mercantilist reality uses the prism of tourism to value and sell everything. Culture is institutionalized, categorized and ready for use, while traditions are staged and resurrected. However, objectively, not all commercial goods and services which contribute to the rise of national gross product are adequate for individuals, society and nature. Commercialization and commodification of culture connected to tourism could potentially destroy the destination's authenticity. Therefore, tourism must take care of the content as well as the economic aspect, in order to provide the tourists with a more productive, cultural and meaningful vacation; one that will help affirm their creative abilities and interests and contribute to their personal improvement. It is, therefore, important to develop selective forms of tourism, so-called special interest tourism, in order to enrich and elevate mass tourism and expand and extend the offer beyond the season.
\end{abstract}

Key words: commercialization, commodification, tourism, heritage tourism, special interest tourism, mass tourism, authenticity

\section{KOMMERZIALISIERUNG DES KULTURERBES IM TOURISMUS}

\section{Mauro Dujmović}

\section{Zusammenfassung}

In einer postmodernen Gesellschaft wird der Tourismus zum Verbrauchsgut. Geschichte, Zeit und Raum als Kulturaspekte werden zur Marktware. In einer allgemeinen Merkantilisierung der Realität wird alles durch das Prisma des Tourismus bewertet und verkauft. Die Kultur ist institutionalisiert, kategorisiert und zum Gebrauch bereitgestellt und Traditionen werden in Szene gesetzt und belebt. Objektiv gesehen sind jedoch nicht alle Kommerzgüter und Dienstleistungen, die das Bruttonationaleinkommen erhöhen, für Einzelne, Gesellschaft und Natur geeignet. Der Tourismus könnte durch die Kommerzialisierung und Kommodifizierung der Kultur und der Lebensweise die Authentizität von Reisezielen vernichten. Neben der wirtschaftlichen Komponente muss der Tourismus auch eine inhaltliche haben, diejenige nämlich, die den Menschen eine produktive, nützliche, mit Kultur erfüllte und inhaltsvolle Erholung ermöglicht, etwas, was die Bejahung ihrer kreativen Fähigkeiten und Interessen ermöglichen und zur Entwicklung ihrer Persönlichkeit beitragen wird. Deshalb ist es notwendig, selektive Formen des Tourismus zu entwickeln, den sogenannten. Tourismus des speziellen Interesses, damit wir den Massentourismus bereichern und veredeln, die Struktur ausweiten und den Zeitzyklus des Angebots verlängern.

Schlüsselwörter: Kommerzialisierung, Kommodifizierung, Tourismus, Tourismus des Erbes, Tourismus des speziellen Interesses, Massentourismus, Authentizität 